\title{
System Dynamics Modeling of Chinese Urban Housing Markets for Pedagogical and Policy Analysis Purposes
}

\author{
Xin Zhang ${ }^{1} \cdot$ David Geltner ${ }^{1}$ (D) \\ Richard de Neufville ${ }^{1}$
}

Published online: 14 March 2018

(C) The Author(s) 2018

\begin{abstract}
This paper reports on the current state of a project to develop a system dynamics (SD) model for urban housing markets in China, aimed at facilitating policy analysis and supporting practical educational tools that might reach large numbers of potential entrepreneurs in China. Although numerous academic papers have applied SD models to real estate markets over the past generation, the technique remains relatively unknown and little used both in the academic economics literature and, more to the point, among practitioners and educators in the real estate community. Yet SD has the potential to address key needs among these constituencies, and extend and complement upon traditional economic methods. SD models are focused on modeling market transitions toward long-run equilibria, facilitating the study of the details of causality and the dynamic path of the market and features that are prominent in the history of housing markets in emerging markets. Different from intensive data-driven economic models, SD models are structural-based operational models that can more easily accommodate the actual non-market features and unique institutional components of these emerging real estate markets, where long-range historical data are not readily available. SD can provide intuitive and transparent model structures that should be able to improve pedagogy for educating large numbers of potential real estate entrepreneurs particularly in emerging market countries. For demonstration, in the present paper we choose to focus on the China-specific features of 'speculative demand' and 'land financing scheme', and use the newly developed SD model to explore the effects of land supply, "command-and-control" versus "market-driven" policies for housing in China. It is important to note, however, that while we chose China for the purposes of our study, the same technique can be applied to any emerging real
\end{abstract}

Xin Zhang

xinzhang@mit.edu

1 MIT Institute for Data, Systems, and Society, and MIT Center for Real Estate, Massachusetts Institute of Technology, 77 Massachusetts Avenue, Cambridge, MA 02139, USA 
estate market. Moreover, our research here can be seen as a stepping stone: Before a generalized SD model for emerging markets can be developed, it is both reasonable and appropriate to construct a model that is constrained to a manageable subset of the overall market space.

Keywords Chinese housing market $\cdot$ System dynamics analysis $\cdot$ Housing system · Housing price simulation $\cdot$ Housing bubble

\section{Introduction}

The past generation has witnessed in China the greatest urbanization in world history to date. China's cities grew by over 500 million people from 1980 to 2015, and this process continues. An estimated 250 million more inhabitants will increase China's urban population by the year 2030. Furthermore, real per capita incomes have been doubling roughly every seven years, and will likely continue to grow rapidly. The result will be a tremendous increase in demand, not only in terms of the quantity but also the quality of urban housing. This will include renovation and redevelopment as well as new stock built on greenfield sites. It is impressive that Chinese cities have, for the most part, accommodated this unprecedented demand. China has achieved this in part through flexible adaptation of the policy framework governing the housing industry. Most notably, it has transitioned from the previous centrally planned social housing system to a largely market-driven system, based on the sale of long-term land leaseholds from local government authorities to private developers. The developers produce the housing, largely units for owner-occupancy, as well as other types of buildings.

In recent years the urban housing system in China has begun to face new challenges. Specifically, in the past decade, the world has witnessed a substantial boom - a golden era - in the Chinese real estate market, with the price of real estate - especially the price of housing - increasing at a rapid rate in major cities. As the industry weakened at the time of the Global Financial Crisis in 2009, the Central Government introduced stimulus policies. While these successfully stemmed the slowdown in the market, they led to a new round of soaring housing prices, notably in some of the "first tier" (or "gateway") cities. These include Beijing, Shanghai, Guangzhou, Shenzhen, and, depending on the source, also possibly Tianjin and Nanjing. This price surge has led to concerns about home affordability in some cities, as well as fears that the market might be exhibiting an asset price "bubble". If such a bubble exists and should collapse, it would wreak havoc in the financial system in China, and could potentially have international implications as well.

The phenomenon of such Chinese housing price escalation has become a popular research topic. Traditional urban economic models such as the pedagogically efficient DiPasquale-Wheaton (D-W) ${ }^{1}$ model have proven to be effective in understanding and analyzing conventional housing market cycles where a free-market economy dominates. However, it faces limitations when being applied to the rapidly developing Chinese markets where political and other non-conventional characteristics play an

\footnotetext{
${ }^{1}$ DiPasquale-Wheaton (D-W) model is also known as the "four quadrant model" (4QM). In this paper, D-W model and 4QM are equivalent.
} 
important role. At the same time, System Dynamics (SD) models have been used to analyze real estate markets over the past generation, yet the technique remains relatively unknown and little used in academia - and, more to the point, among practitioners and educators in the real estate community. The research topics that apply SD to real estate models are scattered around different areas of interests, and thus they do not provide a holistic view.

This paper bridges between economic model and SD models by developing a novel housing system simulation model using the system dynamics technique, anchored on traditional urban economics theory. The proven D-W model provides the theoretical foundation for the SD model's building process. The SD model in turn enhances the flexibility and unleashes the simulation power of D-W model by modifying the assumptions of previous components, as well as incorporating new components to lead to new findings.

\section{Chinese Characteristics: Speculative Demand and Land Financing Scheme}

Behind the potential Chinese housing bubble, there is a concern that the demand for housing units in some of the first and second tier cities includes a large component of buyers that simply use these units as means of storing monetary wealth, rather than as dwelling units to meet the demand for housing needs. Such "speculative" housing demand effectively uses housing as an investment and should be counted as the major reason of the soaring housing price (Guo and Huang 2010). The rapidly rising housing prices provide an environment for exuberant expectations, and the speculation in the housing market might be further stimulating the existing housing boom (Dreger and Zhang 2013). This phenomenon is probably due in part to the fact that China is still in the process of developing the type of broadly diversified system of mature capital markets and financial industry that is necessary to provide rationally priced and transparent investment opportunities of sufficient depth and scale to accommodate the population's rapidly accumulating private wealth. For various reasons, many of the speculative demand housing units are simply vacant, not rented out, wasted in terms of actually providing housing to anybody. ${ }^{2}$

It has also become clear that the housing market is linked to the local governments' public finance system in a manner that is perverse and ultimately unsustainable. Local governments now obtain a crucial proportion of their revenue from the sale of land leaseholds that developers pay for entirely up front at the time of sale (rather than by annual rental payments that might be based on current housing values). Yet the revenue from the sale of land leaseholds highly depends on their price and availability in the marketplace. The obvious risk is that the local governments' need for revenue to service debts and invest in other infrastructure projects could become the driver of land development - rather than the actual market demand based on the need for housing.

\footnotetext{
${ }^{2}$ The Southwestern University of Finance \& Economics Household Finance Survey in 2013 and 2015 found a nationwide average vacancy rate over $22 \%$, based on a survey of over 28,000 households. Evidence suggests that vacancy in third and fourth tier cities is greater than this average.
} 
In the first tier cities such as Beijing and Shanghai, housing developers have already complained that the profit margin has been squeezed to nothing because the land supply is limited, which results in high land bidding prices. In other words, "the cost of flour is more expensive than the price of bread". As a result, the developers must raise the housing price significantly in order to make a profit. It is this scarcity of land, and the resulting housing price increase that is considered to be the root of the potential housing bubble.

Numerous studies have shown that receipts from the sale of land lease rights are the main source for local governments' debt servicing payments (Ding 2003; Hsing 2010; Wu et al. 2012; Lu and Sun 2013). Based on land transaction data from 1999 to 2007, sales of land counted for more than $30 \%$ of local governments' budgets (Liu and Jiang 2005; Li and Luo 2010). Local governments also use the potential revenue from land sales as collateral for a second round of money-raising. Although they are not allowed to borrow directly from government-owned central banks, they can do so indirectly through subsidiary entities using land transfer fees (leasehold sales revenue) or potential conversionin-progress agriculture land stock as collateral (Liu and Zhang 2010). By June 2014, local governments in 84 key cities in China had a total debt of 8700 billion RMB, equivalent to about 1500 billion US dollars (Zhang 2014). As a fraction of GDP, this debt is comparable to the U.S. municipal bond market. To repay the debt, the municipalities are forced to borrow more money, or sell more land that they have immediate access to, thus potentially getting trapped in a vicious cycle (Yang and Huang 2010).

In this situation, a drop in prices for real estate and land could hurt the ability of local governments to service their debt and their local government-financing platform (LGFP). This would impair the asset quality of national banks (Sheng and Soon 2015). The leverage of debt has magnified the effect of the initial large amount of land sales fees. Since land is a scarce and fixed resource, such continuous "self-financing" will not last forever.

Speculative investment and land financing scheme are two unique elements of the Chinese market that are not generally found in well-developed western economies. We point out that this is just two of many characteristics in the Chinese market. But as well, there could be unique characteristics of other markets in the developing economies of other countries that could affect housing price - and therefore, could be modeled using SD techniques. The Chinese market itself has evolved to a complex system encompassing multiple political and social characteristics that do not exist in mature market-based economies such as the US and Europe. It is thus important to find possibly new ways to study, analyze and understand this system, to enable participants and policy makers to make informed decisions and effective policy interventions. To achieve this goal, one needs to develop a systematic model of the Chinese housing market that taken into considerations of key characteristics of the market and observe how they interact with each other. In this paper, the eventual preliminary system dynamics model developed for the Chinese housing market is certainly less ambitious in achieving a complete systematic framework but it is a first step in addressing the important Chinese market features and incorporating them into one simulation framework. 


\section{Literature: From Urban Economics to System Dynamics Modeling}

There is a long and substantial history of modeling real estate markets from the system perspective in the urban economics literature. Though the antecedents go back at least to Hendershott and Ling (1984), much of the modern literature has been based on, or effectively reflects, a particularly compelling and eloquent depiction of the inter-related markets for the usage of built space and for the ownership of property assets, including the role of the development industry in construction and demolition of assets, known as the "four quadrant model" (4QM), proposed by DiPasquale and Wheaton (1992, 1996). Although the basic 4QM represents rental property, we can apply the essence of the model to owner-occupied property as well if we think of the rent as "imputed rent" or the annual value of the service flow of the built space to its users. ${ }^{3}$ The 4QM represents the long-run equilibrium in the real estate market system. It is simple and eloquent in its evocation of the overall system, and serves as a great pedagogical device.

The $4 \mathrm{QM}$ is not particularly oriented toward depicting dynamics - that is, how the system changes over time from one long-run equilibrium to the next. It is true that the model can be "played with" to gain some insight about dynamics, for example as described in Geltner et al. (2014) Chapter 2. But this type of "playing" with the 4QM is informal and vague in its positive implications. Colwell (2002) describes a series of elaborations of the original DiPasquale-Wheaton 4QM that can account directly and explicitly for the long-run equilibrium and address other simplifications in the simple model. But these enhancements undercut the eloquence and pedagogical value of the original model, and do not provide any explicit dynamics, tending to reinforce the model's focus on long-run equilibrium rather than on transition paths toward such equilibria.

The urban economics literature has addressed this deficiency with a stream of models that are essentially formal elaborations of the 4QM into systems of simultaneous linked equations. These "stock-flow models" do indeed represent the dynamics of the market. Econometric analysis can calibrate them with empirical data about rents and occupancy and construction, as observed in actual real estate markets. This stream of literature dates to at least to Rosen (1984). Wheaton, and Wheaton and Torto (Wheaton 1987; Wheaton and Torto 1988; Wheaton et al. 1997; Wheaton 1999) did most of the development, and Hendershott (1995), Hendershott et al. (2002a, 2002b), Hendershott and MacGregor (2005), Hendershott et al. (2010) provided substantial enhancements. Though first developed for office markets, we can in principle apply these types of models to any real estate market sector. ${ }^{4}$

The stock-flow models from urban economics are powerful and practical tools that sophisticated elements in the real estate investment industry in the U.S. and other

\footnotetext{
${ }^{3}$ In the 4QM the space market (market for the use of built space) is referred to as the "property market," while the market for the ownership of the property asset is referred to as the "asset market." In the case of owneroccupied properties, the two markets are tightly linked, though may still be usefully distinguished conceptually for analytical purposes. One may conceive of the owner-occupant as renting to and from himself.

${ }^{4}$ See Ibanez and Pennington-Cross (2013) for a review and a survey of applying the modeling to 34 major metropolitan areas and four space market sectors in the United States. Stock-flow models have also been applied to London and a few other global cities that have substantial data on the space market and construction industry history.
} 
mature markets have used successfully. Analysts commonly take these economic models as a sort of "canonical" starting point for system dynamics models of urban real estate systems. From the perspective pf urban economics, the objective of system dynamics (SD) models is not to negate or supplant the stock-flow models, but to complement and extend them, elaborating them in some aspects.

The behavior of system oscillation is one of the key research focuses in the SD field. And the fundamentals of the SD technique reside in the feedback structure from the complex system behavior, captured by the causal loop diagrams. Causal loop can be either balancing or reinforcing: balancing loops control the system behavior and bring it back to a stable stage, while reinforcing loops allow the system behavior to escalate. In that sense, it is not hard to notice that the stockflow model developed by DiPasquale and Wheaton (1996), and advanced by Wheaton (1999) is fundamentally a balancing loop. That is the reason why the real estate market price in the 4QM model, although it oscillates, does not escalate beyond control and always returns to some level of equilibrium.

Sterman (pp 698-706, 2000) independently proposed a case study using the system dynamic technique to explain the boom and bust of commercial real estate markets without using the 4QM. The model itself is driven by market expectation and the sole purpose is to explain the cyclical behavior by focusing on investors' ignorance of ongoing construction in the pipeline. If we carefully study the causal loops in Sterman's model, it's not hard to notice that the essence is still in the 4QM framework, except that the factors of expectation and time delay for adjustment are accounted for. Both urban economic theories and system dynamics methodologies target similar issues by using stock-flow theory of highly durable goods as well as the myopic behavior of real estate developers to explain the housing market dynamics. This suggests that in the real estate market research field, traditional urban economics models in the form of stock-flow models, and the system dynamics models may have more commonalities than differences.

Unlike econometric methods, which are essentially data-driven models, system dynamics models are structure-based operational models driven by causal relationships and simulation. In particular, urban economists have long noted that the econometric models may become too complex or data-hungry if they try to include certain unique or special features, typically institutional characteristics, of particular markets. ${ }^{5}$ It is also difficult for the purely econometric models to incorporate certain behavioral characteristics of key system actors. For example, it is difficult for a typical stock-flow model to represent the effect of something like the extra speculative demand, or the exogenous land sales/development interventions, that are important characteristics of Chinese urban housing markets. The econometric stock-flow models are generally data intensive, requiring long time series of historical data. This makes them difficult to apply in many emerging market situations where little reliable data is available currently, let alone for long histories. In general, the econometric models lack flexibility in their ability to explicitly depict particular elements, causal flows, and actors' behaviors that can be observed empirically and can be important both for understanding system behavior and in analyzing policies and decisions. This includes key elements in the system such as explicit consideration of the nature and role of land supply and land

${ }_{5}^{5}$ Discussions can be found in Wheaton (1999), Smith and van Ackere (2002), and Eskinasi (2012). 
price. Finally, the econometric models can be difficult to visualize and grasp, making them challenging to communicate to decision makers and of limited use for pedagogical purposes to non-specialized audiences.

The thesis of this paper is that SD modeling can address many of these challenges in the stock-flow models. We demonstrate that the SD model can be graphically altered to incorporate unique market characteristic for which there may be limited historical data or that may be difficult to model by empirical equations. We use the case of certain characteristic present in the current Chinese urban housing markets as an example to demonstrate how the SD model can be adapted. But we point out that this same technique could be applied to any emerging real estate market. Finally, we show how the results of this model can prove useful for purposes of policy research and/or teaching young real estate entrepreneurs.

\section{Model Building: The Basic Simulation Platform Shifts from 4QM to SD Model}

As noted, system dynamicists often take the $4 \mathrm{QM}$, or its more formal dynamic elaboration in the stock-flow model, as a basic starting-point platform for building a SD model of a real estate market (Barlas et al. 2007; Mashayekhi et al. 2009; Eskinasi 2014; Zhang 2017). In the present case we take the Wheaton (1999) model as a highly influential and somewhat canonical representative, and use it as a basic platform for our development of an SD model for Chinese markets. ${ }^{6}$ In this section we describe a basic SD model of a real estate market that exactly replicates the 1999 Wheaton stock-flow model. This serves as starting point, and demonstrates that our initial SD model properly reflects the classical urban economics literature. In subsequent sections we describe some initial exploration of modifications and enhancements to this basic model, in order to explore the application to an emerging market - in our case, China.

The setup in this basic SD model mimics that of the Wheaton (1999) stock-flow model, which is calibrated to a hypothetical U.S. aggregate office market. The model begins with an initial employment work force of 10 million (demand), occupying 2500 million square feet of office space (stock). The initial equilibrium rent is $\$ 20$ per square feet per year. With a market cap-rate of 5\%, the asset price is $\$ 400$ per square foot. At the initial stage, the construction rate equals the demolition rate and the market is in

\footnotetext{
${ }^{6}$ One discrepancy should be noted. The stock-flow models generally pertain most directly to markets for rental properties. Yet the Chinese urban housing market, though it includes an important rental segment, is primarily a for-sale housing market. There can be important differences in the functioning of the equilibrium for such markets. Wheaton (1990) elaborated a model of the market for owner-occupied houses that focuses on some unique features of such markets. He notes that, regarding turnover within the existing quantity of houses and households (apart from change in aggregate demand and supply), every buyer is also a seller and each move creates a temporary vacancy. This consideration is beyond the scope of the present paper. However, SD models of housing systems have been built that explicitly model the vacant stock as a loop in the system (see, e.g., Barlas et al. 2007, and Mashayekhi et al. 2009), and could be incorporated into our model for China. But to date the Chinese urban housing market is characterized primarily as an aggregate-growth market for new housing, with turnover of existing stock playing a relatively minor role. Hence, while we explicitly model "special" vacancy in the form of a system dynamic loop to represent speculative demand, we do not in the present paper model traditional turnover vacancy.
} 


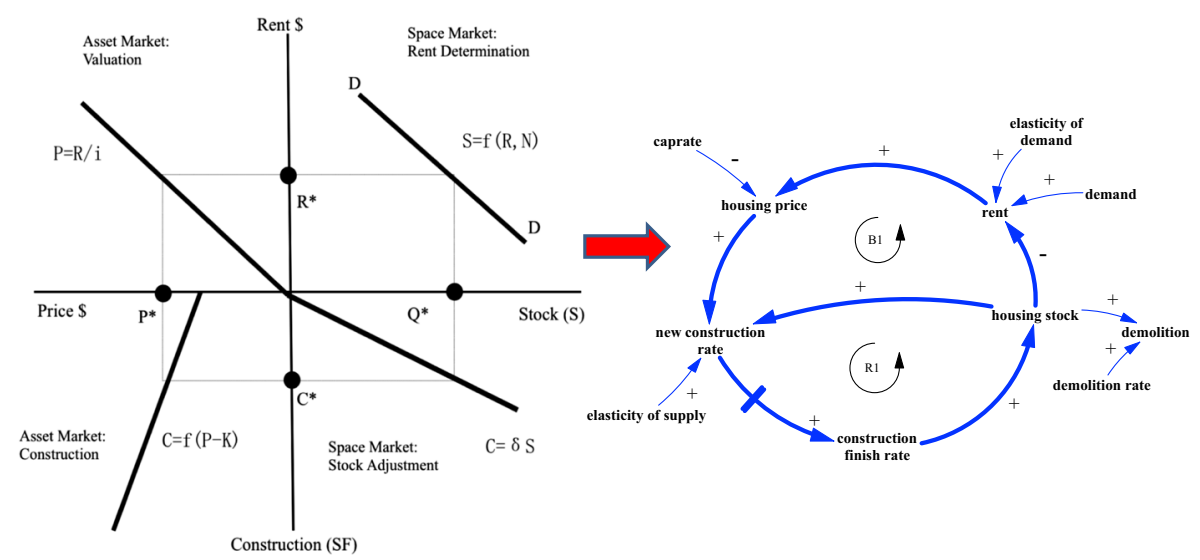

Fig. 1 The causal loop diagram representation of the DiPasquale-Wheaton model

equilibrium. The elasticities in the basic Wheaton model and our SD model are -0.4 for demand, and 2.0 for supply.

Figure 1 presents the causal loop diagram of the DiPasquale-Wheaton model (4QM) and Fig. 2 presents the SD replication of this classical stock-flow dynamic system as in Wheaton (1999). We can follow the causal relationships indicated by the arrows to see, for example, how the impact of a sudden increase in demand is reflected through the real estate markets. In the beginning, because the increase in demand (from 10 million to 15 million) was unexpected, the supply of office space, namely, the current 'stock', remains unchanged. As a result, as indicated by the red arrows, the rent rises. The cap rate (asset market yield) remains constant, ${ }^{7}$ so the rent increase leads to an increase in the price of property assets, as shown by the green arrows. A rising property price triggers reaction in the stock-flow part of the SD model, which occurs along the main double-arrow flow from left to right. From the supply side, the developers increase construction rate responding to the higher asset prices (greater development profitability), aiming to meet the increased usage demand that led to the price increase. The newly finished construction adds to the stock. This added stock will offset the ongoing demolition, which is assumed to be proportional to the pre-existing stock. In such a system model we can expect the stock to keep rising until it meets the new, increased level of demand, after which the increased supply will start to bring down the rent and thus the property price. When the price starts to drop, the construction will slow down, bringing the stock to a level that will be maintained net of demolitions so that the entire real estate system reaches a new steady-state equilibrium.

In simulated solutions using the numerical settings described in the Fig. 3 caption, the SD model indicates that a 50\% demand jump instigates the dynamic oscillations in the system shown in the chart. The simulation of SD model for this paper is conducted by using Vensim Software from Ventana Systems, Inc. ${ }^{8}$ The simulation results exactly

\footnotetext{
${ }^{7}$ Cap rate is short for capitalization rate. It is essentially the rent-to-price ratio and is the yield that investors demand in order to hold the real estate assets. In Wheaton (1999), the cap rate is treated as an exogenous variable. Its value is determined based on the long-term interest rates and returns in broader capital market for assets in other categories.

${ }^{8}$ For detailed software coding, please contact authors.
} 


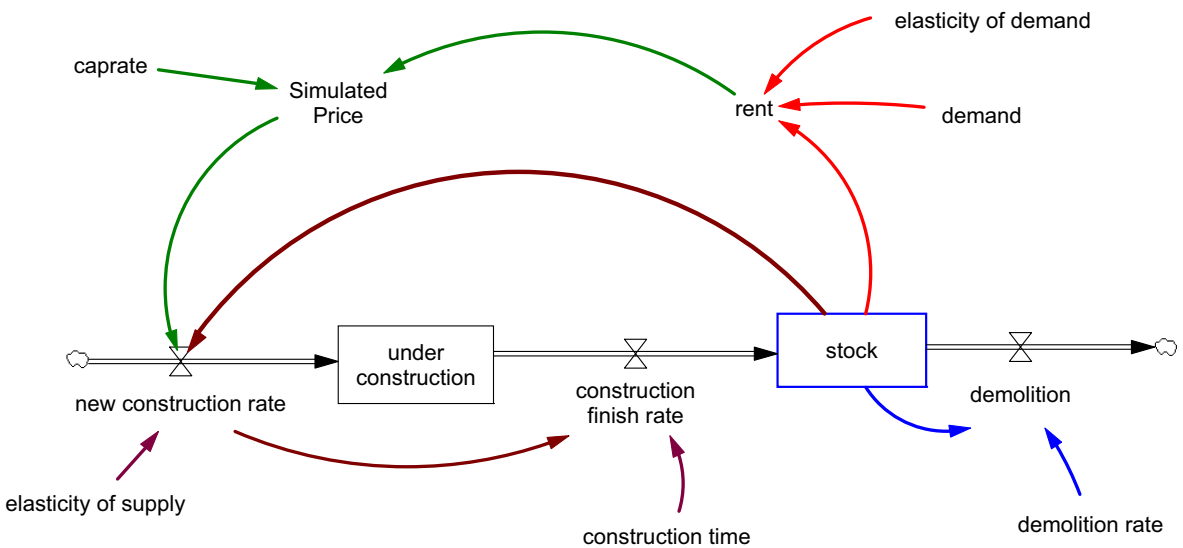

Fig. 2 The SD representation of the stock-flow model in Wheaton (1999)

replicate those shown in Wheaton (1999). Given the parameter values used in the simulation, the price variable oscillates and has difficulty reaching a steady state, which was the main point of Wheaton (1999). However, consistent with the stock-flow literature, the SD model allows us to see that certain combinations of parameters (such as relatively more elastic supply compared to demand) will lead the price back to a steady state after a short period of oscillation.

\section{Model Modification: Testing Alternative Assumptions of the SD Model}

Even for such a simple basic replication of a stock-flow model, the SD model can bring additional insight and discovery. Unlike the stock-flow model, the SD model can more flexibly elaborate explicit causal mechanisms and processes in the system. For example, the SD model enables us to see that the classical stockflow model implicitly assumes what in system dynamics is called a "pipeline delay structure" in the completion of construction starts. This assumes that individual items exit the delay queue in the same order they entered and after exactly the same processing time. The SD model can only replicate the type of
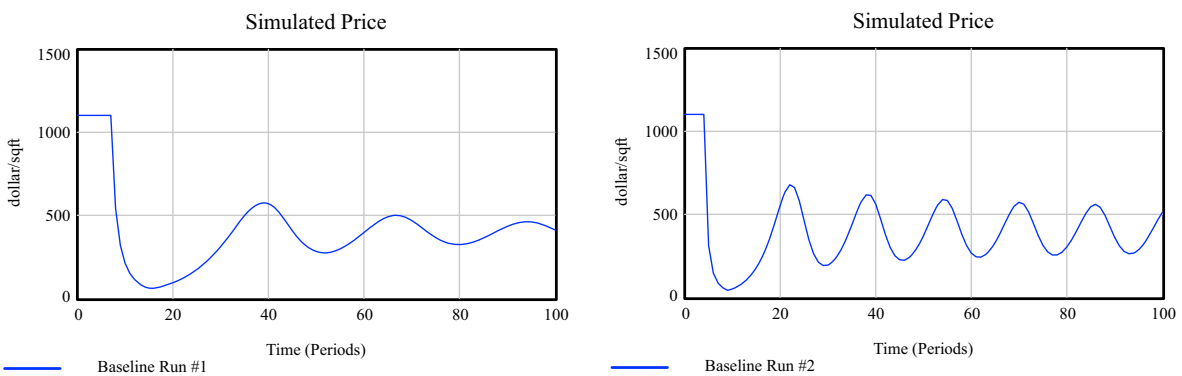

Fig. 3 Replication of Wheaton (1999) stock-flow model simulation results. Baseline model run \#1 to the left: Market reaction to a $50 \%$ demand shock (lag: $n=8$; depreciation rate: $\delta=0.05$; demand elasticity $=-0.4$; supply elasticity $=2.0$ ). Baseline Model Run \#2 to the right: Market reaction to a 50\% demand shock (lag: $n=$ 5 ; depreciation rate: $\delta=0.10$; demand elasticity $=-0.4$; supply elasticity $=2.0$ ) 
oscillation associated with the Wheaton (1999) stock-flow model if we assume the pipeline type of delay structure. But suppose the real estate system does not exhibit this kind of construction delay. Instead, suppose for example that greater volume of construction corresponds to the constraint of construction resources in one region, resulting in a construction completion rate that is proportional to the stock of property under construction. This is what SD terminology calls a "firstorder material delay structure." Such resources cannot follow the exact schedule of the pipeline structure as determined by the developers' investment expectations (Sterman 2000). Also, there are mixed types of housing properties that require different lengths of construction time. Making assumptions that they will start and finish at the same time is not realistic. The comparison of pipeline delay and firstorder delay structures is shown in Fig. 4.

Figure 5 shows how the SD model framework accommodates a first-order material delay structure. The modification from the basic SD model is circled by an oval outline. The "under construction" variable is used as a device to count all the housing units that are under construction at each point of time. The exit rate, or construction completion rate, equals the "under construction" stock amount divided by the construction time. The visual difference from the basic SD model is that the arrow coming into the "construction finishing rate" is no longer directly from the "new construction rate" but from the "under construction" stock variable.

Figure 6 shows that the first-order material delay structure can dampen the oscillations and speed the return to steady state in the asset price dynamics. The first local maximum exhibits a higher price jump than in the classical model, but after that the system shows less oscillation and reaches a price steady state much quicker. Under the same system parameters, the first-order delay structure can result in a more stable system. This could have policy implications, such as calls for provisions to streamline construction during periods of rapid housing demand

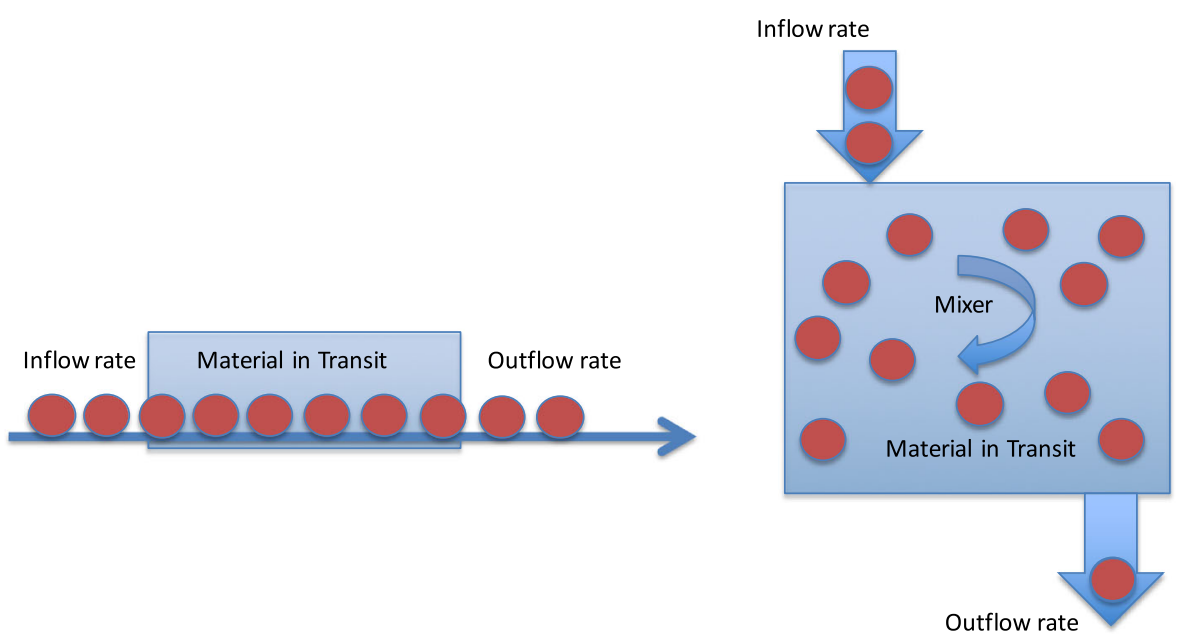

Fig. 4 Pipeline delay structure vs. first-order delay structure. Left panel: pipeline delay structure; Right panel: first-order delay structure. The key difference resides in the relationship between 'Material in Transit' and 'Outflow' 


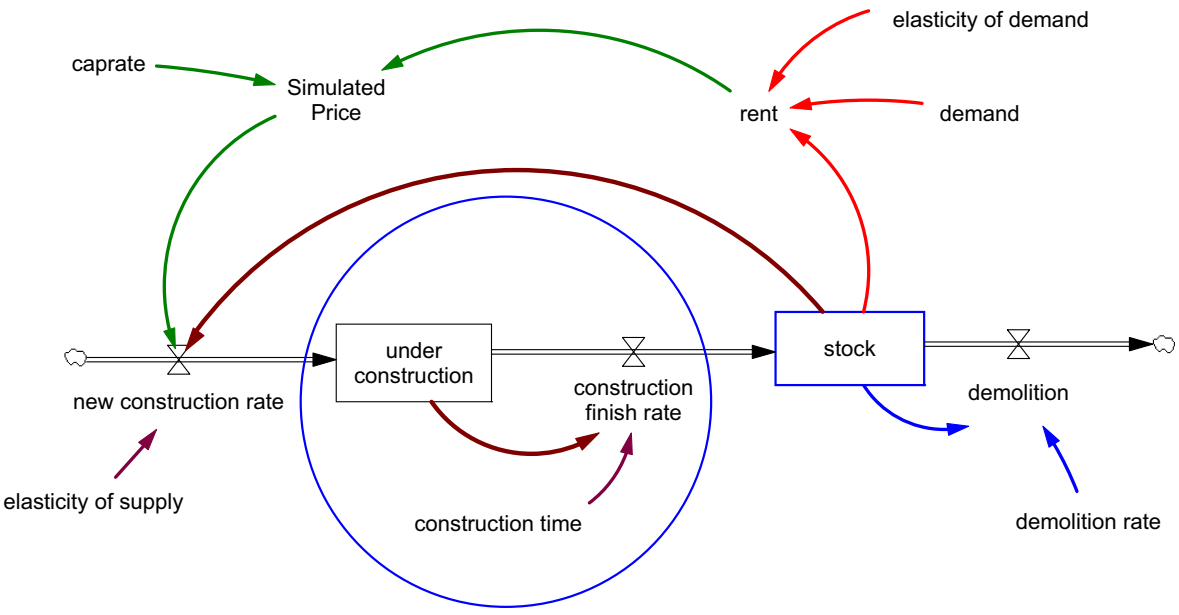

Fig. 5 Construction delay switches from pipeline to first-order delay structure

growth, and/or to enforce a more deliberate rate of development when and where housing demand is not growing so fast. It also might more realistically represent the real estate market if developers hire extra construction resources when demand is great. But our main point here is that the SD model allows one to "open up" causal mechanisms in the system and represent them more explicitly and flexibly by using analog models.

\section{An Attempt: Developing a SD Model to Incorporate Chinese Market Features}

In the remainder of the paper we modify the basic SD model to represent certain key features of Chinese urban housing markets. First, we calibrate the model to Chinese parameters using the historical data of one of the major second tier cities in China. In this paper, we refer to it as City A. Then, we introduce two unique and important "nonmarket" features of the Chinese system that have been observed in City A and covered in previous section: the reliance on land finance scheme (which is implied by the high

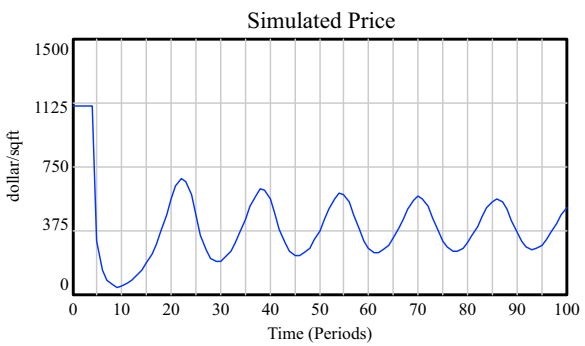

Simulated Price : Pipeline delay structure

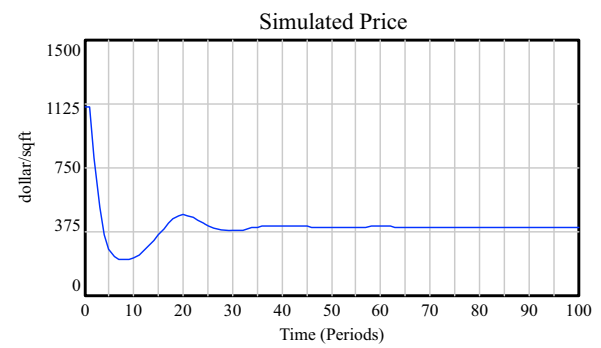

Simulated Price : First-order delay structure

Fig. 6 The price oscillation is dampened with first-order delay structure. Left hand side graph shows the price oscillation effect using a pipeline model for construction delivery structure, and Right hand side graph shows that price oscillation reduced significantly when construction delivery structure is modified to a first-order delay structure with the same construction period ( $\mathrm{n}=5$ periods) 


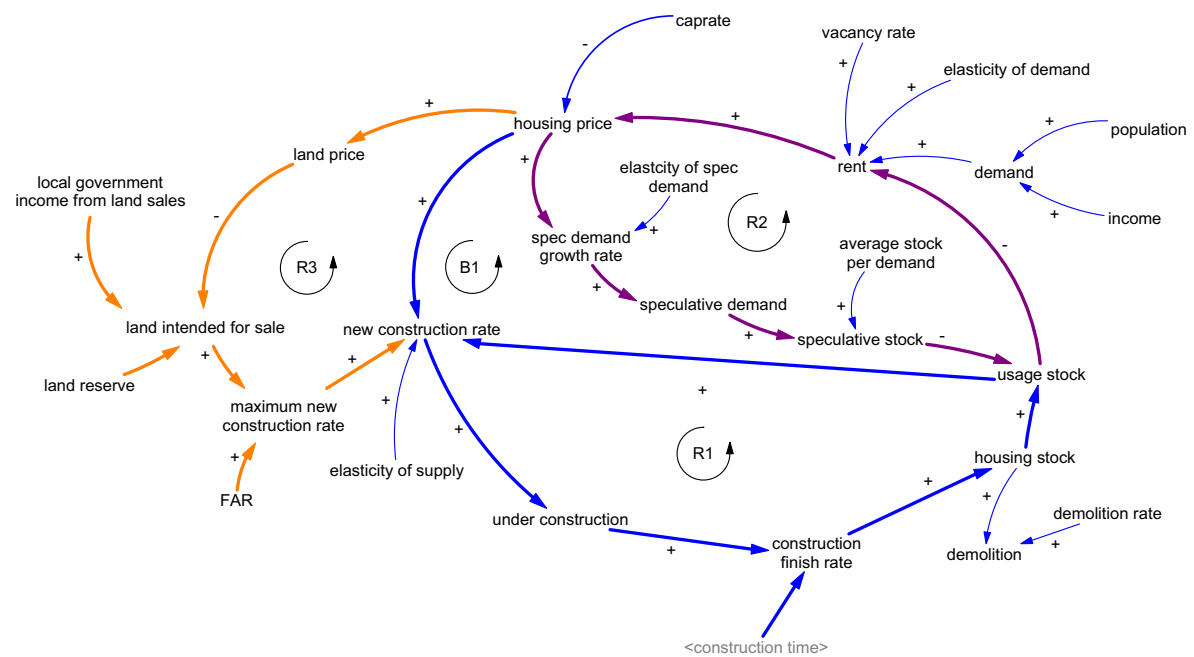

Fig. 7 The causal relationships of the integrated sd model with both speculative demand component (in purple) and land financing component (in orange)

percentage of land sales income divided by the government's general revenue), and the prominence of speculative demand (which is implied by a high price-to-rent ratio). The structure and equations of the SD model are easily modifiable for the purpose of integrating special features; they can be "plugged-in", that is, added onto the basic model as extra elements or modules.

The preliminary model in its Causal Loop Diagram (CLD) form and SD form that includes both speculative demand component and land financing component is shown in Figs. 7 and 8.

\section{Incorporating Speculative Demand}

We modified the model structure to include the market total vacancy rate through two components: natural vacancy rate and speculative vacancy rate. The natural vacancy rate reflects the usage demand in the same sense as in the urban

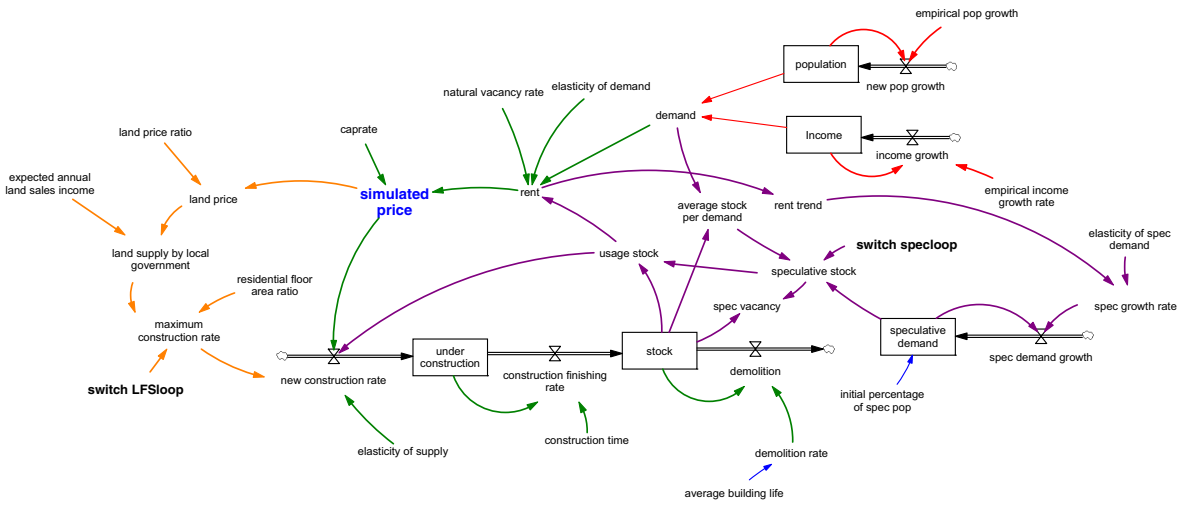

Fig. 8 Integrated system dynamics model including the speculative demand and land financing components 
economics literature. We approximate this rate as $5 \%$. The speculative vacancy rate relates to the speculative demand and is conceptually different from natural vacancy. Speculative housing units remain vacant. It is only possible to crudely estimate the relatively large share of the inventory that speculative demand holds in the City A's housing market. The total vacancy rate is the sum of the usage (natural) vacancy rate and speculative vacancy rate. For example, if the speculative vacancy rate in City $\mathrm{A}$ is $15 \%$, then its total vacancy rate equals $5 \%+15 \%=$ $20 \%$. We then apply the total vacancy rate to the total stock variable. For example, when total stock is at 1000 units, then $20 \%$ of the units are vacant, which equals to 200 units. Among them, 50 units are natural vacancy, while 150 units are speculative vacancy.

The important point is that speculative vacancy impacts house price change contrary to the normal effect of natural vacancy. With natural vacancy, when prices rise, usage demand decreases as buyers seeking actual housing stay out of the market. This increases natural vacancy and creates a downward pressure on price - it brings price back into balance. However, when prices rise, the speculative demand will also increase, as speculative buyers are lured by anticipated future returns on their investment. It thereby increases the speculative vacancy rate without having any dampening effect on the market prices. On the contrary, it pushes the market price upward. However, when the price is going down, more speculative investors will sell their vacant units, and this will create additional downward pressure on prices. To reflect the logic above, we have added the loop of speculative demand as marked in purple color in Fig. 7.

To incorporate this feature, we needed to add the "rent trend" variable to the model to capture the price percentage change from one period to the next period during simulation, assuming that the speculative demand is more sensitive to price changes than to absolute price levels. For this component, we have set up the speculative demand as a stock-flow model and assumed a simple relationship between the speculative demand growth rate (speculative investors buy in) and the rent trend (see in full model), by using the elasticity of speculative demand. The simple linear relationship assumption is due to the fact that the research of speculative vacancy rate remains limited in China.

\section{Incorporating the Land Financing Component}

According to the residual theory of land value, the land price should equal the housing price minus the construction cost and developer's profit margin. This reflects the maximum price that the real estate developers are willing to pay for the land. Through a competitive bidding process, this should equal to the market price of the land in a classical competitive market economy. In this simplified model, we assume that the land price is a percentage of the housing price. In China, the situation of land supply is different from other countries with market economy. First, the central government nominally owns all land in China and strictly controls a land quota system that sets the maximum amount of land that local governments can make available for development. Second, local governments determine their land sales based on budget considerations. The amount they incented to sell equals their budget divided by the land price. 
This amount may differ from year to year for various reasons but it sets an upper limit to the real estate system governing how much new construction can happen every year.

The model incorporates the possibility of representing alternative ways the local government might act to determine its budget, either to:

- "Maximize revenue", that is, to sell as much land as possible as long as it is under the land quota or

- "Fixed revenue" that is, to supply land until sales meet revenue requirements.

The main causal loop relates land prices to local government land sales behavior, which in turn affects the stock of housing in the market, which in turn affects rents and house prices, and then, via the Residual Theory, land prices are affected once again. The loop is shown as the orange loop in Fig. 7. We take these alternatives of either "maximize revenue" or "fixed revenue" as two extreme cases in the land supply spectrum. At this point we make no assumption about the actual behavior of the local government of City A. However, we believe that, in reality, the system is typically somewhere in-between the two extremes and we simply examine each case as an archetype. When the local government is revenue maximizing, the system does not tend overly toward house price bubbles. The key point is that rising land price leads the revenue-maximizing local government land sales authority to sell more land acreage. This leads to an increase in the supply of housing, which puts downward pressure on rents and/or house prices, which in turn closes the loop in a dampening manner by putting downward pressure on land prices, thereby counteracting or dampening the initial trigger which was rising land prices. ${ }^{9}$

On the other hand, when the local government land sales authority is aiming at a "fixed revenue" type of target, the relationship between the "land price" and "land sales" variables is a negative relationship. This changes the main land-financing loop from "balancing" to "reinforcing" in SD terminology. An increase in land price now causes the local government land sales authority to reduce the amount of land sales (in acreage), as selling less acreage of land will suffice to meet the fixed revenue budget target due to the higher land price per acre. Thus, higher land prices lead to less land sales which results in less stock of housing in the market than would otherwise occur, in spite of rapidly growing housing demand (reinforced by speculation loop). The reduced (or less rapidly growing) housing supply drives up rents and prices, leading to higher land prices (again via the Residual Theory), and the loop continues in an upward spiral.

Complementarily, the model also incorporates the possibility of representing alternative ways private developers react to the local government's land sales, including the following two archetypes:

- "Command-\&-Control" (as in planned economy) or

- "Market-Driven" (as in market economy).

\footnotetext{
${ }^{9}$ We have not yet incorporated, but can easily do so and will do, the effect of local government artificially constraining the proportion of residential land sales in favor of industrial land. This could be reflected in another decision node in the system in which the local government decides on the proportion of land sales that is to be residential.
} 
The effect of these alternative responses is to influence the variable "new construction rate".

The key characteristic in the "command-\&-control" pattern is more like in a planned economy that all the land sold by the local government is eventually converted to finished housing stocks and supplied to the market. The assumption for this case is that, following the direction of the local government, the local developers absorb the entire supply of land at the system-implied price (which of course, reflects the rents, which in turn reflect the supply and demand balance) and start to develop the land almost instantly instead of hoarding it. In this system, the new construction rate equals to the maximum construction rate that is jointly decided by the local government's budget need and the land price. While this may represent a simplified and somewhat extreme or archetypical case, it will be instructive for analytical purposes.

In contrast, what we call the "market-driven" system assumes that developers are profit-maximizers similar to private sector capitalistic firms. For example, when the market is down, they will not purchase land from the local government. Or, even if they have purchased land, they can and will choose not to develop the land immediately. In this case, the decision-making process of private developers is the key driving force. The supply of new land for development from the local government only establishes an upper limit or ceiling on the amount of new development; it does not fix a definite amount of development.

Table 1 Exogenous variables and the data source for City A

\begin{tabular}{|c|c|c|c|}
\hline $\begin{array}{l}\text { Exogenous variable } \\
\text { name }\end{array}$ & Units & $\begin{array}{l}\text { Time range } \\
\text { (Year) }\end{array}$ & Variable data source \\
\hline Annual land sales & RMB & $2006-2011$ & China Land and Resources Statistical Yearbook \\
\hline Elasticity of demand & Dmnl (Dimensionless) & 2005 & $\begin{array}{l}\text { Zheng and Liu (2005) Estimated } \\
\text { value of }-0.86\end{array}$ \\
\hline Elasticity of supply & Dmnl & 2012 & Wang et al. (2012) Estimated value of 3.42 \\
\hline Housing Price & $\mathrm{RMB} / \mathrm{sqm}$ & $2006-2015$ & $\begin{array}{l}\text { National Data from National Bureau } \\
\text { of Statistics of China } \\
\text { http://data.stats.gov.cn }\end{array}$ \\
\hline Land price & $\mathrm{RMB} / \mathrm{sqm}$ & $2006-2011$ & China Land and Resources Statistical Yearbook \\
\hline $\begin{array}{l}\text { Land supply by local } \\
\text { government }\end{array}$ & Sqm & 2006-2011 & China Land and Resources Statistical Yearbook \\
\hline $\begin{array}{l}\text { Local government } \\
\text { annual revenue }\end{array}$ & RMB & 2006-2015 & China City Statistical Yearbook \\
\hline Per capita income & RMB/person & $2006-2015$ & City A’s Statistical Yearbook \\
\hline Population & Persons & 2006-2015 & City A's Statistical Yearbook \\
\hline Residential FAR & Dmnl & 2007-2012 & $\begin{array}{l}\text { www.landchina.com Calculated value } \\
\text { of } 1.55\end{array}$ \\
\hline
\end{tabular}

The data of some of the variables are not actually used in the model but to provide the reference value to set up hypothetical data range 
Table 2 Variables with initial values to set up the equilibrium stage for SD model simulation

\begin{tabular}{llll}
\hline Initial variable for City A & Units & Initial salue @ Year 2006 & Data source \\
\hline Initial average stock & Sqm/person & 26 & Online source $^{\mathrm{a}}$ \\
Initial government revenue & $\mathrm{RMB}$ & $24,643,920,000$ & China City Statistical Yearbook $^{\text {Initial population }}$ \\
Initial per capita income & Persons & $6,072,000$ & City A Statistical Yearbook \\
Initial price & $\mathrm{RMB} /$ person & 17,538 & City A Statistical Yearbook \\
& $\mathrm{RMB} / \mathrm{sqm}$ & 4270 & National Data from National \\
Initial rent & $\mathrm{RMB} / \mathrm{sqm}$ & 214 & Bureau of Statistics \\
Initial total stock & $\mathrm{Sqm}$ & $157,872,000$ & Calculated \\
Natural vacancy rate & $\mathrm{Dmnl}$ & $5 \%$ & Calculated \\
\hline
\end{tabular}

${ }^{\mathrm{a}}$ The data is quoted from Nanjing Chenbao (Morning Nanjing) published on 29 September, 2006. http://news. qq.com/a/20060929/001418.htm. Accessed 25 June 2015

\section{Formulations, Data, and Simulation Results of the Integrated Model}

\section{Model Formulations and Data Source}

Here we re-calibrate the previous basic SD model to reflect China, using the best available data from the City A that are listed in details in Tables 1,2 and 3. The data are also considered semi-hypothetical because the key data for the modeling process such as speculative vacancy rates are not available. We make reasonable assumptions for the illustrative purposes of this paper, which is to demonstrate how SD methodology can be used to study the system behavior with some pedigree in the literature, and can provide interesting results for gaining insight into the system behavior. It is important to emphasize that the goal of this paper is not to mimic the real housing price trends in exact details but to show how different market features interact with each other in a systematic framework.

Table 3 Variables with estimated values for City A

\begin{tabular}{|c|c|c|c|}
\hline Estimated variable name & Units & $\begin{array}{l}\text { Estimated } \\
\text { value }\end{array}$ & Data source \\
\hline Average building life & years & 20 & $\begin{array}{l}\text { Author's assumption based on } \\
\text { online source }\end{array}$ \\
\hline Cap rate & Dmnl & $5 \%$ & $\begin{array}{l}\text { Author's assumption based on } \\
\text { online source }\end{array}$ \\
\hline Construction time & years & 2 & $\begin{array}{l}\text { Author's assumption based on } \\
\text { online source }\end{array}$ \\
\hline Initial percentage of speculative population & Dmnl & $5 \%$ & Author's assumption \\
\hline Land price ratio & Dmnl & $40 \%$ & Estimated based on past trend \\
\hline Natural vacancy rate & Dmnl & $5 \%$ & Author's assumption \\
\hline Spec demand elasticity & Dmnl & 2 & Model Calibrated \\
\hline
\end{tabular}


The initial stock represents the number of housing units in City A in 2006. The land auction system was established in 2004. As a result, the land price before 2004 does not reflect the actual land value and we choose year 2006 as a starting point for modeling. Along with the demand function, and the elasticity of demand, the stock jointly determines the current rent level in the market. The "rent" in the model represents a "shadow rent" that reflects the household's ability to pay off the annual mortgage payment. The model assumes that the demand function for housing depends proportionately on two exogenous economic variables, population and per capita income growth. The model assumes that the multiplication of population and income, which is the GDP of City A, responds to the shadow rent with constant demand elasticity. The change in population will be due to the natural growth/death rate, as well as net migration from other cities and regions.

The "shadow rent" defined above, when divided by the market cap rate, reflects the current market price for a housing unit in the asset market. Then, the initial housing price (assumed to be $4270 \mathrm{rmb} / \mathrm{sqm}$ ), construction cost, and the elasticity of supply will jointly determine the rate of new construction. After a fixed delay time, normally 2 years due to the permitting and construction process, the "new construction rate" will become the "construction finish rate" and will add to the total stock. We assume that the developers, once they start construction, will follow the schedules and finish the construction in order.

There are no consensus values for either supply and demand elasticities in the literature for the Chinese market. According to Wang et al. (2012), the supply elasticity is possibly around 3.42 for City A. According to Zheng and Liu (2005), the demand elasticity is set around -0.86 . In the present model, we assume that supply is more elastic than demand and both elasticities remain constant throughout the simulation periods. However, the supply elasticity has some temporal effect because it is subject to the influence of actual land supply change. Same temporal effect applies to the demand elasticity which is influenced by the speculative demand component. We also assume that the average building life determines the annual demolition rate, as a percentage of existing stock. For example, if the design life of the residential units is 20 years, then the demolition rate will be $1 / 20=5 \%$ per year.

\section{Simulation Results and Main Findings}

\section{Using Historical Data (2006-2015)}

First, we used historical data of City A, from year 2006-2015 and applied it to the basic SD model which mimics the D-W model. The results show that the basic SD model translated from D-W model does not fully explain the historical housing price of City A. Both trend and scale of simulated housing price are off from the historical data. When we apply the historical dataset to the integrated model with only land financing scheme incorporated, the price trend shifted from cyclic behavior to an increasingly rising pattern. When we apply the same data to incorporate only speculative demand component, minimal effects are found. It is because the speculative demand is sensitive to the price change. As a result, when we apply the dataset to speculative demand component on top of land financing scheme component, significant price effects are found, and the historical housing price of City A can be explained. The simulation process and results are shown in Fig. 9. 

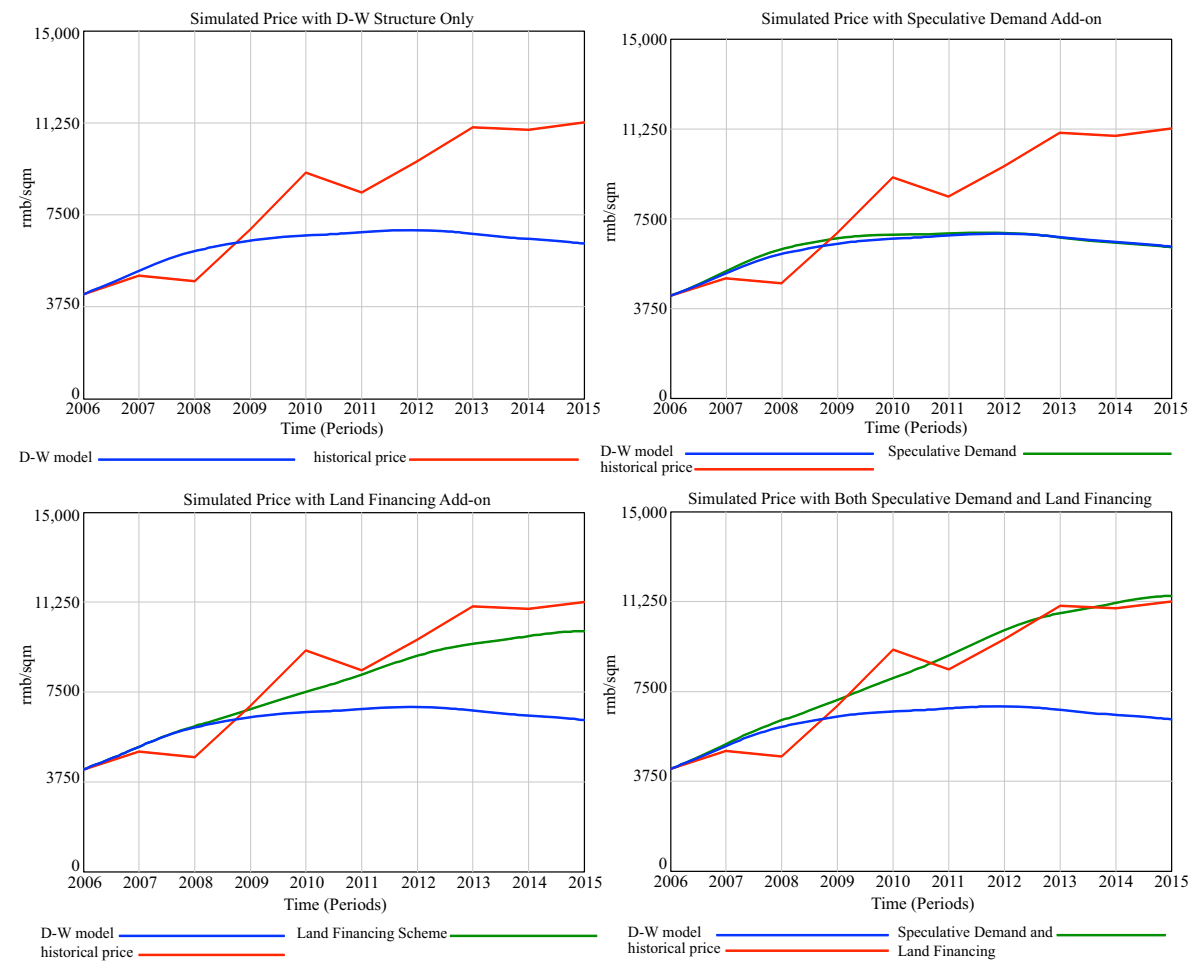

Fig. 9 Simulated housing price with D-W, speculative demand, and land financing scheme added on individually

Through the historical simulations, we believe that the land supply constraint imposed by the land financing scheme is the fundamental driving force behind the price increase in City A. The land financing scheme serves as an amplifier and can significantly magnify the price effect of other market features, especially the ones that are sensitive to price change, such as speculative demand.

\section{Varying Local Government's and Developer's Decision-Making Process from Year 2010}

We do not know how the local government of City A decides on the amount of land supply every year but we believe that it is highly related to the local government's revenue. If the local government were revenue maximizers, then the land market would behave just like in a traditional market where the amount of land supply is decided by the

Table 4 Local Government's land financing scheme and developers' reaction

System

Fixed-revenue target of City A

\begin{tabular}{lll}
\hline & Low @ 20 billion yuan & High @ 200 billion yuan \\
Command-\&-Control (CC) & Scenario Low-CC & Scenario High-CC \\
Market Driven (MD) & Scenario Low-MD & Scenario High-MD \\
\hline
\end{tabular}


"invisible hand" in the housing market. However, it is interesting is to analyze the scenario where the interest of local government is not aligned with the market demand, such as in the situation where the local government were raising "fixed revenue". We run the model to consider the possible consequences of different assumptions discussed in previous section, as shown in Tables 4 . We also assume the assumptions happen in year 2010 .

- The local government's decision about the amount of revenue they wish to raise (low target or high target); and

- The consequent responses of the developers ("command-\&-control" or "market driven").

The simulation results are shown in Fig. 10. In the scenario where the fixed budget is at the low level, we can see that the "command-\&-control" system and "marketdriven" system generate the same result. The resulting simulated housing price is even higher than the actual historical price. This is because the higher housing price will lead to higher land price, and as a result, the land needed for sale is reducing every year from the local government's perspective. The scarcity of land supply from the local government pushes developers to pay premium prices to purchase the land and the resulting scarce supply of new housing pushes up the housing price enabling developers to pay the higher land prices. This scenario can happen when the local government is a land hoarder and expects the land price to continue rising in the future.

However, when the fixed budget is high, we can see that the "market-driven" system avoids the downward price trend that the "command-\&-control" system produced. This is because rational private developers abstain from the market and have the option not to buy or develop all the land the government makes available. In the "command- $\&$ control" system however, the developers are merely taking commands from the local government to build at maximum allowed. This essentially is the cause of the "ghost city" case, where local government sells all the land upfront to reach the land sales income target, and developers build at maximum capacity expecting the demand increase in the future to absorb the housing units. However, that future demand never materializes and the result is a "ghost city".

\section{Model Validation and Testing}

The model is validated through the following standard system dynamics model validation process listed in Sterman (2000). We have extended the model boundaries and more features that are considered relevant in determining the Chinese urban housing prices are included into the system, comparing to the initial D-W urban economic model, such as speculative demand, land financing scheme, etc. The structure assessment test for the integrated models is consistent with the descriptive knowledge of the concept of the housing system in China. The modification made to add speculative demand and land financing scheme in the Chinese housing market are supported with empirical evidence as discussed in previous section. The dimensional consistency, or "units checking" is performed for the integrated model. The only issue is that the scaling parameters are without actual meaning. Their definitions and equations however, makes 
dimensional consistency test difficult. For the parameter assessment, the numerical values of the model variables and their data source are listed in details in Tables 1, 2, and 3 .

The SD models are also tested with extreme conditions, meaning each equation makes sense even when its inputs take on extreme values. For example, when demand of the integrated model is set to zero, the rent and housing price would be driven to zero. It is also important to know that the initial state of the integrated model is at equilibrium using City A's data in year 2006. In other words, when the demand remains unchanged (without a step jump or exponential growth), the system will remain at equilibrium. The purpose of the integrated model is not to fit data to the historical housing price point to point. We aim to first get the simulated price trend correct and then to see if simulated price is in the range of historical housing price.

The sensitivity analysis is conducted with regard to key variables with estimated value, such as the price elasticity of speculative demand. There is no recorded data or measurement for this parameter. For example, the current value for simulation is estimated at 2.0. We have run sensitivity analysis and give the elasticity a uniform distribution between the value of 1.75 and 2.25. The test result is shown in Fig. 11. The range of speculative vacancy is between the minimum of $7.5 \%$ and the maximum of $22.5 \%$ which are consistent with various sources of estimation (Huang 2015; Glaeser et al. 2016; Wu et al. 2016; Gan 2017).

\section{Conclusion}

This paper presents a new line of analysis for real estate development and markets that builds on the traditional econometric methodology. Starting from wellestablished theory and methods, the approach follows in the footsteps of previous SD applications to urban systems, to propose a useful way to examine the dynamics of real estate markets, particularly in contexts where these are subject to a range of controls different from those existing in Western market economies. Our initial focus is on China, but we believe it would be reasonable to apply this approach to other rapidly urbanizing regions, such as South East Asia, India, and elsewhere. The essence is to understand how to use SD techniques to model the non-traditional behavior of certain markets - behaviors that are created and influenced by local conditions.

The stock-flow model of real estate markets provides the core conceptual framework for the analysis. Its emblematic representation, the DiPasquale-Wheaton 4QM, focuses primarily on a static equilibrium analysis. But the stock-flow model elaborates some key features of real estate market dynamics, as a number of previous studies have shown for mature markets where historical data is plentiful. But we need to make analytical tools more general and flexible, with greater richness of system elements, explicit causal flow representation, and more ability to accommodate non-market and unique institutional features in data-scarce environments typical of emerging market. A convenient and established way to do this is to use the tools of systems dynamics (SD). These have the advantage, compared to econometric systems of equations with lagged 


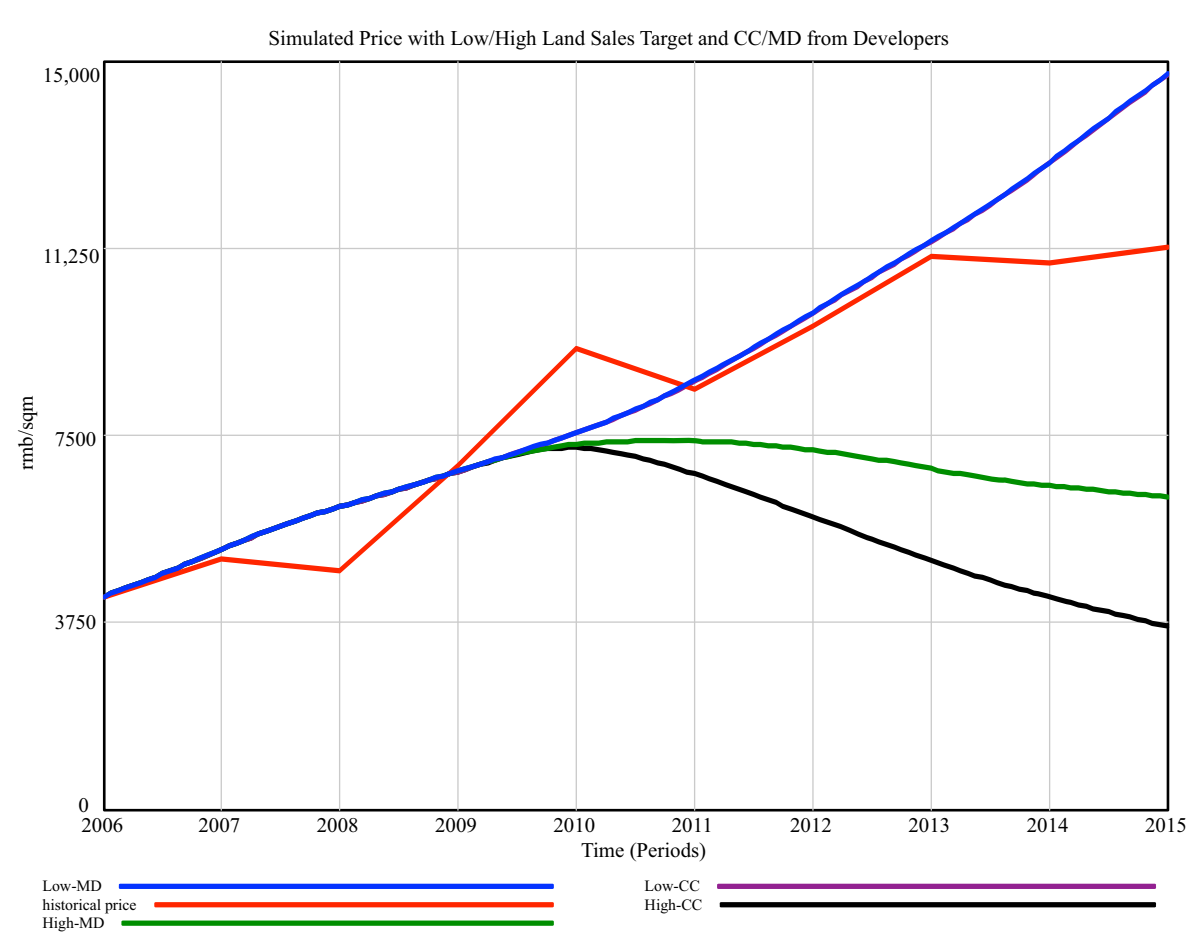

Fig. 10 Simulation results of low/high (hypothetical) land sales target from local government of City A and "Command-\&-Control" / "Market-Driven" from evelopers. Note: Simulation result of "command-\&-control" system when two hypothetical levels of "fixed revenue" target of local government for City A applied from year 2010 on. (Low $=20$ billion yuan, and High $=200$ billion yuan). Blue line denotes the price rise due to limited land supply triggered by low revenue target. Green line denotes the price drop due to high revenue target but developers are rational. In this case private developers have the option not to buy or develop all the land the government makes available. Black line denotes the price drop due to high revenue target but the developers are merely taking command to build at maximum allowed. Red line represents historical data

variables, of providing reasonably comprehensive images and explanations, often analog in nature, of the dynamic effects that balance and dampen the dynamics of a market, or reinforce them in explosive bubbles or collapses.

The approach in this paper builds on a canonical SD representation of the stock-flow model. The idea is to explore the possible implications of specific features or restrictions on real estate markets. Procedurally, we embed representations of these features into the basic canonical model and explore their possible interactive effects. It is one of the first preliminary engineering models built for the Chinese housing market and a possible use of the model is for teaching purposes. ${ }^{10}$

We then use this model to explore the possible implications of the "land financing system" that has developed in China. This process puts local governments in charge of assembling and releasing land for development, and has allowed them to use this process as a "cash cow" to generate needed municipal revenues. Using actual historical data, we have found the magnifying effect of land supply constraints imposed on the

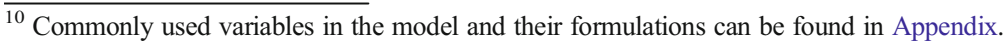



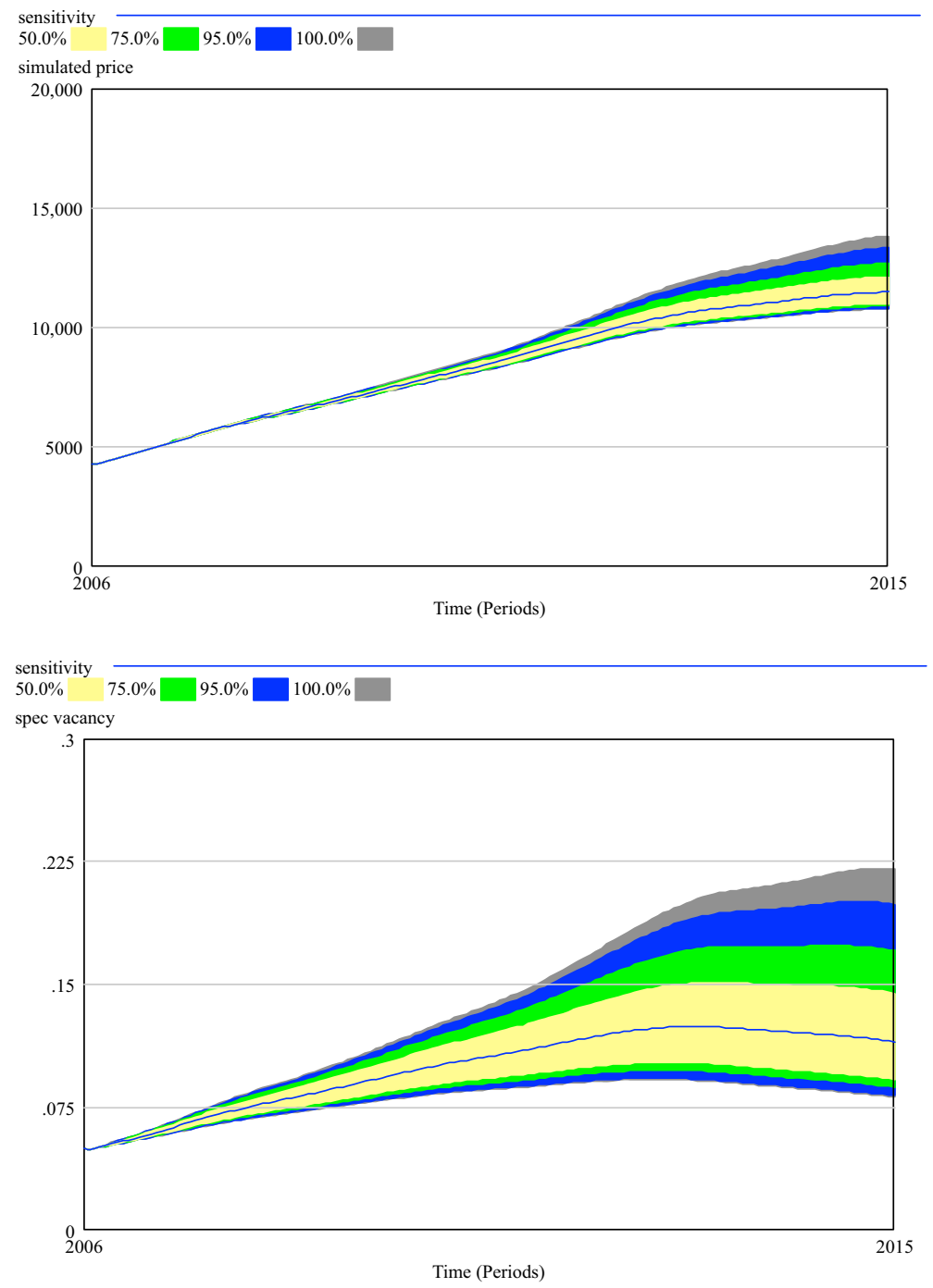

Fig. 11 Sensitivity test for elasticity of speculative demand with a uniform distribution U[1.75, 2.25]. Upper image: Price trend and range; lower image: range of speculative vacancy rate

housing system. Through the interactive process within the housing system model, the land supply has the ability to magnify the effect of other price-sensitive components such as speculative demand.

Finally, we analyze the interactive decision-making process of local government's land supply scheme, as well as the response from private developers. The simulations reported herein suggest that this process can lead to house prices either rising to unsustainable levels, if the local government land sales revenue target is low; or to prices collapsing if the local government's revenue target is high and the system operates in a "command-\&-control" manner as in planned economy. 


\section{Appendix}

Table 5 Commonly used variables in the model and their formulation

\begin{tabular}{|c|c|c|}
\hline Variable & Formulation and comments & Units \\
\hline Alpha 1 & $\begin{array}{r}=\text { initial rent } \wedge \text { elasticity of demand } * \text { initial usage } \\
\text { stock }^{*}(1-\text { natual vacancy rate }) / \text { initial demand }\end{array}$ & NA \\
\hline Alpha 2 & $=$ demolition rate $/$ initial price $^{\wedge}$ elasticity of supply & NA \\
\hline Average building life & Exogenous constant & Years \\
\hline $\begin{array}{l}\text { Average stock } \\
\text { per demand }\end{array}$ & $=$ stock $/$ demand & $\mathrm{Sqm} / \mathrm{RMB}$ \\
\hline Cap Rate & Exogenous constant & Dmnl \\
\hline Construction finish rate & $=$ under construction $/$ construction time & Sqm/year \\
\hline Construction time & Exogenous constant & Year \\
\hline Demand & $=$ Population $*$ Income & RMB \\
\hline Demolition rate & $=1 /$ average building life & Dmnl/year \\
\hline Demolition & $=$ stock $^{*}$ demolition rate & Sqm/year \\
\hline Elasticity of demand & Exogenous constant & Dmnl \\
\hline $\begin{array}{l}\text { Elasticity of speculative } \\
\text { demand }\end{array}$ & Exogenous constant & Dmnl \\
\hline Elasticity of supply & Exogenous constant & Dmnl \\
\hline $\begin{array}{l}\text { Empirical income } \\
\text { growth rate }\end{array}$ & Exogenous & Dmnl \\
\hline $\begin{array}{l}\text { Empirical population } \\
\text { growth }\end{array}$ & Exogenous & Dmnl \\
\hline $\begin{array}{l}\text { Expected annual land } \\
\text { sales income }\end{array}$ & Exogenous & RMB \\
\hline Equilibrium switch & Binary 1 or 0 & Dmnl \\
\hline Historical price & Exogenous & $\mathrm{RMB} / \mathrm{sqm}$ \\
\hline Income growth & $\begin{aligned}= & \text { Income*empirical income growth } \\
& \text { rate*equilibrium switch }\end{aligned}$ & $\mathrm{RMB} /$ year \\
\hline Income & $=$ INTEG (income growth, initial income) & $\mathrm{RMB} /$ person \\
\hline Initial average stock & Exogenous & Sqm/Person \\
\hline Initial demand & $=$ INITIAL (initial pop*initial income) & RMB \\
\hline Initial income & Exogenous constant & RMB/person \\
\hline $\begin{array}{l}\text { Initial percentage of } \\
\text { speculative pop }\end{array}$ & $=$ Exogenous constant*Equilibrium switch & Dmnl \\
\hline Initial pop & Exogenous constant & Persons \\
\hline Initial price & Exogenous constant & $\mathrm{RMB} / \mathrm{sqm}$ \\
\hline Initial rent & $=$ INITIAL(initial price*Initial cap rate) & $\mathrm{RMB} / \mathrm{sqm}$ \\
\hline Initial total stock & $=$ INITIAL(initial average stock*Initial pop) & Sqm \\
\hline Initial usage stock & $=$ initial total stock $*(1$-initial percentage of spec pop) & Sqm \\
\hline Land price & $=$ price $*$ land price ratio & $\mathrm{RMB} / \mathrm{sqm}$ \\
\hline Land price ratio & Exogenous constant & Dmnl \\
\hline Land supply by local & $=$ expected annual land sales income/land price & Sqm \\
\hline
\end{tabular}


Table 5 (continued)

\begin{tabular}{|c|c|c|}
\hline Variable & Formulation and comments & Units \\
\hline $\begin{array}{l}\text { Maximum construction } \\
\text { rate }\end{array}$ & $\begin{aligned}= & \text { if then else }(\text { switch LFSloop }=1 \text {, land supply by local } \\
& \text { government*residential floor area ratio, } 1 \mathrm{e}+20 \text { ) }\end{aligned}$ & Sqm/year \\
\hline Natural vacancy rate & Exogenous constant & Dmnl \\
\hline New construction rate & $\begin{aligned}= & \min (\text { maximum construction rate, usage } \\
& \left.\text { stock } * \text { alpha } 2 *(\text { simulated price })^{\wedge} \text { elasticity of supply }\right)\end{aligned}$ & Sqm/year \\
\hline Population & $=$ INTEG (new pop growth, Initial pop) & Persons \\
\hline Rent & $\begin{aligned}= & \left(\text { usage } \text { stock }^{*}(1-\text { natural vacancy rate }) /\right. \\
& (\text { alpha } 1 * \text { demand }))^{\wedge}(-1 / \text { elasticity of demand })\end{aligned}$ & $\mathrm{RMB} / \mathrm{sqm}$ \\
\hline Rent trend & $=$ TREND (rent, Time STEP, 0) & Dmnl \\
\hline Residential FAR & Exogenous Constant & Dmnl \\
\hline Simulated Price & $=\mathrm{rent} /$ caprate & $\mathrm{RMB} / \mathrm{sqm}$ \\
\hline Spec demand growth & $=$ spec growth rate* speculative demand ${ }^{*}$ equilibrium switch & $\mathrm{RMB} /$ year \\
\hline Speculative demand & $\begin{array}{l}\text { = INTEG (spec demand growth, } \\
\text { initial demand*initial percentage of spec pop) }\end{array}$ & $\mathrm{RMB}$ \\
\hline Spec growth rate & $=$ rent trend $*$ elasticity of spec demand & Dmnl \\
\hline Speculative stock & $\begin{aligned}= & \text { average stock per demand* }{ }^{*} \text { speculative } \\
& \text { demand*switch specloop }\end{aligned}$ & Sqm \\
\hline Spec vacancy & $=$ speculative stock $/$ stock & Dmnl \\
\hline Stock & $=$ INTEG $($ construction finish rate-demolition, initial total stock) & Sqm \\
\hline Switch LFSloop & Binary 1 or 0 & Dmnl \\
\hline Switch specloop & Binary 1 or 0 & Dmnl \\
\hline Under construction & $\begin{aligned}= & \text { INTEG (new construction rate-construction finish rate, } \\
& \text { initial stock }{ }^{*} \text { demolition rate*construction time) }\end{aligned}$ & Sqm \\
\hline Usage stock & $=$ stock - speculative stock & Sqm \\
\hline
\end{tabular}

*RMB stands for Chinese Current Renminbi; Dmnl stands for dimensionless

Open Access This article is distributed under the terms of the Creative Commons Attribution 4.0 International License (http://creativecommons.org/licenses/by/4.0/), which permits unrestricted use, distribution, and reproduction in any medium, provided you give appropriate credit to the original author(s) and the source, provide a link to the Creative Commons license, and indicate if changes were made.

\section{References}

Barlas, Y., Birnur Ö., \& Onur Ö. (2007). Modeling of real estate price oscillations in Istanbul. In Proceedings of the 2007 System dynamics conference. URL: http://www.systemdynamics.org/conferences/2007 /proceed/papers/BARLA342.pdf

Colwell, P. F. (2002). Tweaking the DiPasquale-Wheaton model. Journal of Housing Economics, 11(1), 24 39. https://doi.org/10.1006/jhec.2001.0301.

Ding, C. (2003). Land policy reform in China: Assessment and prospects. Land Use Policy, 20(2), 109-120. https://doi.org/10.1016/S0264-8377(02)00073-X.

DiPasquale, D., \& Wheaton, W. C. (1992). The markets for real estate assets and space: A conceptual framework. Real Estate Economics, 20(2), 181-198. https://doi.org/10.1111/1540-6229.00579. 
DiPasquale, D., \& Wheaton, W. C. (1996). Urban economics and real estate markets. Englewood Cliffs: Prentice Hall. https://doi.org/10.4018/978-1-4666-7230-7.

Dreger, C., \& Zhang, Y. (2013). Is there a bubble in the Chinese housing market? Urban Policy and Research, 31(1), 27-39. https://doi.org/10.1080/08111146.2012.711248.

Eskinasi, M. (2012). Collected system dynamics works on recent real estate dynamics. 30th international conference of the system dynamics society, St. Gallen, Switzerland. URL: https://www.systemdynamics. org/conferences/2012/proceed/papers/P1087.pdf

Eskinasi, M. (2014). Towards housing system dynamics: Projects on embedding system dynamics in housing policy research. Eburon Academic Publishers, Delft, The Netherlands.

Gan L. (2017). Housing Market and Urbanization. Presentation made on February 16, 2017 At Samuel Tak lee lab, Massachusetts Institute of Technology. URL: https://stl.mit.edu/news/li-gan-“"ghost”-towns-why-50million-housing-units-china-are-vacant

Geltner, D., Norman, G.M., Clayton, J., \& Eichholtz, P. (2014). Commercial real estate analysis and investments. Cincinnati, OH: South-Western.

Glaeser, E., Huang, W., Ma, Y., \& Shleifer, A. (2016). A real estate boom with Chinese characteristics. National Bureau of economic research, NBER working paper, no.W22789, https://doi.org/10.3386 /w22789.

Guo, F., \& Huang, Y. (2010). Does "hot money" drive China's real estate and stock markets? International Review of Economics and Finance, 19(3), 452-466. https://doi.org/10.1016/j.iref.2009.10.014.

Hendershott, P. H. (1995). Real effective rent determination: Evidence from the Sydney office market. Journal of Property Research, 12(2), 127-135.

Hendershott, P. H., \& Ling, D. (1984). Prospective changes in tax law and the value of depreciable real estate. Journal of the American Real Estate \& Urban Economics Association (AREUEA), 12(3), 297-317. https://doi.org/10.1111/1540-6229.00324.

Hendershott, P. H., \& MacGregor, B. D. (2005). Investor rationality: Evidence from UK property capitalization rates. Real Estate Economics, 33(2), 299-322. https://doi.org/10.1111/j.1540-6229.2005.00120.x.

Hendershott, P. H., MacGregor, B. D., \& Tse, R. (2002a). Estimation of the rental adjustment process. Real Estate Economics, 30(2), 165-183. https://doi.org/10.1111/1540-6229.00036.

Hendershott, P.H., MacGregor, B.D., \& White, M.J. (2002b). Explaining real commercial rents using an error correction model with panel data. Journal of Real Estate Finance and Economics 24(1)\&24(2), 59-87.

Hendershott, P. H., Lizieri, C. M., \& MacGregor, B. D. (2010). Asymmetric adjustment in the city of London office market. Journal of Real Estate Finance and Economics, 41(1), 80-101. https://doi.org/10.1007 /s11146-009-9199-6.

Hsing, Y. (2010). The great urban transformation: Politics of land and property in China. Oxford University Press, Inc. New York. ISBN:978-0-19-956804-8.

Huang, H.Z. (2015). Discussion on China's housing market: What we know, what we don't. Paper presented at the international symposium on housing and financial stability in China, Shenzhen, China, December 18-19, 2015. URL: https:/www.imf.org/external/np/seminars/eng/2015/HousingChina/pdf/Session2_ HHuang.pdf

Ibanez, M. R., \& Pennington-Cross, A. (2013). Commercial property rent dynamics in US metropolitan areas: An examination of office, industrial, flex and retail space. Journal of Real Estate Finance and Economics, 46(2), 232-259. https://oi.org/10.1007/s11146-011-9347-7.

Li, S., \& Luo, B. (2010). Estimation of the size of Chinese land finance. Journal of Central University of Finance \& Economics, 5, 12-17.

Liu, S., \& Jiang, X. (2005). Financial risks of land financing by local governments - case study of a developed area in East China. China Land Science, 5, 3-9.

Liu, Y., \& Zhang, C. (2010). Analysis of Chinese local government's financing platform. Banker to The World, $6,48-52$.

Lu, Y., \& Sun, T. (2013). Local government financing platforms in China: A fortune or misfortune?. International Monetary Fund research, IMF working paper no.13/243. Available at SSRN: https://ssrn. com/abstract=2375564.

Mashayekhi, A.N., Ghili, S., \& Pourhabib, A. (2009). Real estate cycles: a theory based on stock-flow structure of durable goods markets. In proceedings of the 2009 System dynamics conference. URL: http://www.systemdynamics.org/conferences/2009/proceed/papers/P1243.pdf

Rosen, K. T. (1984). Toward a model of the office building sector. Real Estate Economics, 12(3), 261-269. https://doi.org/10.1111/1540-6229.00322.

Sheng, A., \& Soon, N.C. (2015). Bringing shadow banking into the light: Opportunity for financial reform in China. Fung Global Institute Asian Perspectives Global Issues (FGI report). 
Smith, P. C., \& van Ackere, A. (2002). A note on the integration of system dynamics and economic models. Journal of Economic Dynamics and Control, 26(1), 1-10. https://doi.org/10.1016/S01651889(00)00025-7.

Sterman, J. D. (2000). Business dynamics: Systems thinking and modeling for a complex world. McGraw-Hill Education. ISBN-10: 9780072389159.

Wang, S., Chan, S. H., \& Xu, B. (2012). The estimation and determinants of the price elasticity of housing supply: Evidence from China. Journal of Real Estate Research, 34(3), 311-344.

Wheaton, W. C. (1987). The cyclic behavior of the national office market. Real Estate Economics, 15(4), 281299. https://doi.org/10.1111/1540-6229.00433.

Wheaton, W. C. (1990). Vacancy, search, and prices in a housing market matching model. Journal of Political Economy, 98(6), 1270-1292. https://doi.org/10.1086/261734.

Wheaton, W. C. (1999). Real estate “cycles”: some fundamentals. Real Estate Economics, 27(2), 209-230. https://doi.org/10.1111/1540-6229.00772.

Wheaton, W. C., \& Torto, R. G. (1988). Vacancy rates and the future of office rents. Real Estate Economics, 16(4), 430-436. https://doi.org/10.1111/1540-6229.00466.

Wheaton, W. C., Torto, R. G., \& Evans, P. (1997). The cyclic behavior of the greater London office market. Journal of Real Estate Finance and Economics, 15(1), 77-92. https://doi.org/10.1023/A:1007701422238.

Wu, J., Gyourko, J., \& Deng, Y. (2012). Evaluating conditions in major Chinese housing markets. Regional Science and Urban Economics, 42(3), 531-543. https://doi.org/10.1016/j.regsciurbeco.2011.03.003.

Wu, J., Gyourko, J., \& Deng, Y. (2016). Evaluating the risk of Chinese housing markets: What we know and what we need to know. China Economic Review, 39, 91-114. https://doi.org/10.1016/j. chieco.2016.03.008.

Yang, W., \& Huang, T. (2010). Risk analysis of Chinese local government's land financing platform. China Finance, 6, 80-81.

Zhang, J. (2014). 84 cities using land finance to take on debt in total of 8 trillion RMB. China Business Journal. URL: http://finance.sina.com.cn/china/20140823/013920097098.shtml. Accessed on 25 July 2015.

Zhang, X. (2017). Potential housing bubble with Chinese characteristics: Analysis and policy design through an operational model. PhD Dissertation. Massachusetts Institute of Technology, Cambridge.

Zheng, S., \& Liu, H. (2005). Income elasticity of housing demand in China: Model, estimation and forecast. China Civil Engineering Journal, 7, 122-126. 